\title{
From the Chair
}

\section{HASA@60}

\section{Karen L. Harris}

This year marks the 60th year of the formation of the Historical Society of South Africa. In typical historical fashion this calls for some form of commemoration, if not reflection, on a historic milestone of both the society as well as its journal. After all, jubilees, anniversaries and centennials of human beings, human associations and human structures, call for some form of acknowledgement and are often cause for recourse to some form of historical pondering. Most times these are reflections that celebrate an unchallenged past, one where the story is sanitised and the past is venerated. HASA and Historia are no exception. Its forefathers (few foremothers) occasionally took stock of what had been achieved on a surprisingly intermittent basis. ${ }^{1}$ At the risk of committing the historical sin of over-simplification and generalisation, as well as being constricted by the editorial word limit, I briefly peruse the tangible voice of HASA in its journal, Historia. It is thus to the past that this brief presidential note turns, while Historia's editor-in-chief and the editorial board look to its future.

Having reflected on the history of HASA in a comparative perspective elsewhere, ${ }^{2}$ this piece turns to some of the issues that have occupied HASA and the pages of its editorials since its inception in 1956. The opening page of the first volume of Historia, which appeared in June of that year, was adorned with a photograph of the governor-general of the Union of South Africa. His Excellence Dr E.G Jansen commented that the issuing of a historical publication could "fulfil an important roll [sic] in our society". ${ }^{3}$ He contended that the "lack of knowledge of our history makes it more difficult to understand the problems which our country has to face" and believed that if the "publication [was] going to help this deficiency it [would] render South Africa a great service". ${ }^{4}$ The editorial of this same inaugural edition also pointed to the journal - and the association - as intending to serve the interests of history in the widest sense. The image of History was portrayed as a house with many rooms which could function differently, but to all intent and purpose were basically

1. Of some 153 issues of Historia, to date less than a third include editorials.

2. K.L. Harris, "Warring Societies? Towards a Community of Historians HASA and SAHS (1956-2014)", Historia, 59, 2 (November 2014), pp 344-354.

3. Historia, 1 (June 1956), p 2.

4. Historia, 1 (June 1956), p 2.

\section{How to cite this article:}

K.L. Harris, "From the Chair. HASA@60/Van die voorsitter. HGSA@60", Historia 61, 1, May/Mei 2016, pp 6-10.

http://dx.doi.org/10.17159/2309-8392/2016/v61n1a2

Copyright: (CThe Author(s). Published under a Creative Commons Attribution Licence. 
held together in order to serve a common goal regarding an interest in the past. ${ }^{5}$ The "openness" of this historic home, reiterated by the editorial on the tenth anniversary of HASA, ${ }^{6}$ was of course dramatically curtailed if not stunted by the political and ideological shutters of the time. Yet when setting the strictures of context and time aside, this image of an accommodating open house resonates very much with the vision expressed by the current executive and editorial board, while its role within the educational domain echoes the position of leading history educationists commenting on the need for history in the context of the recent xenophobic attacks. ${ }^{7}$

In line with this image, its proclaimed policy was an open house language policy, although at the time this was exclusively Eurocentric. Afrikaans was the official founding language, but contributions were accepted in English, Dutch, German and French and were duly published in their original language. ${ }^{8}$ While HASA and Historia were essentially Afrikaans, from the outset there were English-speaking members and articles appeared in English from the very first volume. ${ }^{9}$ Subsequently, English articles (with summaries in Afrikaans) predominated as the membership and readership gradually became more inclusive of southern African societies. Interestingly this stance on language also resounds with comments of the current editorial board in a climate where language is a particularly hotly contested issue in the tertiary educational arena.

Dipping into the message of an editorial a decade later, the take on history as being indispensable to both the individual and the "volk" persisted. The mature allwhite male editorial team contended that this conviction and concern was still prevalent, claiming that the task of HASA could never be regarded as complete. ${ }^{10}$ The profile of HASA remained for the most part relatively unchanged as the chairman (no chairwoman until the twenty-first century) held office for periods ranging from seven years to a quarter of a century. Historia's editorship followed a similar pattern in that the first nine editors were based at one particular tertiary institution, only moving to others for the subsequent five. Of these seventeen editors (including a duo and trio), only three in the past decade have been female with the current chairperson being the first woman. While this may appear as a critique of HASA, it is very much a reflection of both the fraternity and its academic profile not only within South Africa but also across the continent and beyond. However, also worth noting is that again, a half century later, it is a young female-led editor who also propounds the importance of the discipline, calling for a need to continue in the "pursuit of reflection and renewal" (see editorial).

\footnotetext{
5. $\quad$ Historia, 1 (June 1956), p 4.

6. Historia, 4 (December 1965), p 222.

7. See, for example, R. Sieborger, "Don't Rob our Pupils of Chance to Study History”, Cape Times, 12 June 2008, p 9.

8. $\quad$ Historia, 1 (June 1956), p 4.

9. Historia, 1 (June 1956), pp 6, 32-35.

10. Historia, 4 (December 1965), p 224.
} 
In its 1986 issue the editorial concern was again about the decline of the interest in history. Three decades down the line this was not only an unease about the educational system, but also about politicians and the broader public, who it was contended were "probably try[ing] to escape from a feeling of guilt resulting from the past mistakes".11 As the country was caught in the grip of the crises of its pretransitional phase, there was a call for a historical consciousness among the youth stating that "we live in a different era, a changed society with common interests and problems which we have to resolve together".12 With the \#RhodesMustFall campaign, another three decades down the line many in the fraternity were concerned that a \#HistoryMustFall campaign would follow. Partisan statements, distorted claims and ignorance appeared to be the name of the game. Yet out of this maelstrom emerged a new look at the past, a revitalisation brought as a result of the student movements which led tertiary institutions, and in particular History Departments across the country, to engage with issues of transformation, re-curricularisation and decolonisation. This in itself is a welcome development which again forefronts the place and power of History.

\section{Van die Voorsitter}

\section{HGSA@60}

Die Historiese Genootskap van Suid-Afrika teken hierdie jaar sy 60ste kerf aan. Dit is dus, eie aan die geskiedkundige gebruik, die gepaste geleentheid vir 'n oordenking oftewel ' $n$ besinning - oor 'n historiese mylpaal vir die genootskap en sy joernaal. Jubileums, herdenkings en eeufeeste, hetsy van mense, menslike genootskappe of mensgemaakte strukture, vereis 'n mate van erkenning en lei ook dikwels tot historiese bepeinsing. Só 'n besinning kan ook ontaard in die viering van ' $n$ onbestrede verlede, 'n witgekalkte verhaal, of 'n geroemde geskiedenis. Wat dit betref is die HGSA en Historia hoegenaamd nie 'n uitsondering nie. Sy voorvaders (daar was weinig voormoeders) het van tyd tot tyd - oftewel elke dan en wan - bestek geneem van alles wat vermag is. ${ }^{13}$ Sonder om die gevaar te loop om die historiese aardsondes van oorvereenvoudiging en veralgemening te pleeg, en gedagtig aan die redaksionele woordbeperking, wil ek nogtans die HGSA se tasbare stem vanuit sy joernaal, Historia, laat opklink. Hierdie kort voorsittersboodskap is dus op die verlede gemik, terwyl Historia se hoofredakteur en redaksionele raad hul blik op die toekoms rig.

\footnotetext{
11. Historia, 31 (May 1986), p 1.

12. Historia, 31 (May 1986), p 1.

13. Uit ongeveer 153 uitgawes van Historia, bevat minder as 'n derde redaksionele artikels.
} 
Aangesien ek al vantevore binne 'n vergelykende raamwerk oor die geskiedenis van die HGSA besin het, ${ }^{14}$ handel hierdie stuk oor sommige van die vraagstukke wat die HGSA en die blaaie van sy redaksionele artikels sedert sy stigting in 1956 besig gehou het. Op die eerste bladsy van die eerste volume van Historia, wat in Junie daardie jaar verskyn het, het daar 'n foto van die destydse goewerneurgeneraal van die Unie van Suid-Afrika gepryk. Volgens Sy Edele dr. E.G. Jansen kon die uitgawe van 'n historiese publikasie "'n baie belangrike rol vervul in ons samelewing". ${ }^{15}$ Hy het aangevoer 'n "gebrek aan kennis van ons geskiedenis beteken minder bekwaamheid om die probleme te verstaan waarmee ons land te doen kry" en indien "die voorgestelde tydskrif gaan help om hierdie gebrek aan te suiwer, sal hy 'n groot diens aan Suid-Afrika bewys". ${ }^{16}$ Die redaksie van dieselfde inhuldigingsuitgawe het ook daarop gewys dat die joernaal - en die genootskap - daarop gemik was om die belange van geskiedenis in die breedste sin van die woord te dien. Geskiedenis is uitgebeeld as 'n huis met baie vertrekke wat verskillend kon funksioneer, maar wat nogtans saamgesnoer is deur 'n gedeelde belang in die verlede. ${ }^{17}$ Die "openheid" van hierdie historiese woning, wat in 'n redaksionele artikel ten tyde van die HGSA se tiende herdenking opnuut beklemtoon is, ${ }^{18}$ was natuurlik dramaties ingeperk, indien nie heeltemal belemmer nie, deur die politieke en ideologiese luike van die tyd. Tog, as mens die stellasies van die konteks en die tyd vir 'n oomblik opsy skuif, resoneer die beeld van 'n akkommoderende, ope huis steeds met die visie van die huidige uitvoerende en redaksionele raad, terwyl sy rol wat betref die opvoedkundige terrein steeds weerklank vind in vooraanstaande opvoedkundiges se kommentaar oor die noodsaaklikheid van geskiedenis, veral gegewe die onlangse vreemdelingehaat en die gepaardgaande geweld. ${ }^{19}$

In lyn met hierdie beeld, was daar ook 'n ope-huis taalbeleid, alhoewel dit destyds bepaald Eurosentries was. Afrikaans was die amptelike stigterstaal, maar bydraes in Engels, Nederlands, Duits en Frans is ook aanvaar, en in hul oorspronklike tale gepubliseer. ${ }^{20}$ Terwyl die HGSA en Historia in wese Afrikaans was, was daar vanuit die staanspoor Engelssprekende lede. Reeds in die eerste volume is daar artikels in Engels gepubliseer. ${ }^{21}$ Daarna het Engelse artikels (met opsommings in Afrikaans) die oorhand gekry, namate die genootskap se lede en sy lesers die wyer suider-Afrikaanse gemeenskap begin insluit het. Dit is interessant om daarop te let dat dit steeds weerklank vind in die kommentaar van die huidige redaksionele raad,

\footnotetext{
14. K.L. Harris, "Warring Societies? Towards a Community of Historians HASA and SAHS (1956-2014)", Historia, 59, 2 (November 2014), pp 344-354.

15. Historia, 1 (Junie 1956), p 2.

16. Historia, 1 (Junie 1956), p 2.

17. Historia, 1 (Junie 1956), p 4.

18. Historia, 4 (Desember 1965), p 222.

19. Raadpleeg, byvoorbeeld, R. Sieborger, “Don't Rob our Pupils of a Chance to Study History”, Cape Times, 12 Junie 2008, p 9.

20. Historia, 1 (Junie 1956), p 4.

21. Historia, 1 (Junie 1956), pp 6, 32-35.
} 
op 'n tydstip wanneer taal weer aan die brandpunt staan van debatte binne die hoër onderwys.

'n Vlugtige kyk na die boodskap van 'n redaksionele artikel 'n dekade later wys duidelik hoe die beskouing van die geskiedenis as onmisbaar vir beide die volk en die individu steeds hoogty gevier het. Die ietwat gryse, deurgaans witte, immer manlike redaksionele span het aangevoer hierdie oortuiging, en die meegaande kommer daaroor, was steeds 'n dwingende saak. Dus kon die HGSA nooit sy taak as afgehandel beskou nie. ${ }^{22}$ Die HGSA se profiel het meerendeels onveranderd gebly, ook wat betref die voorsitters (daar was geen voorsitster voor die een-en-twintigste eeu nie). Hul termyne in die voorsitterstoel het gewissel van sewe jaar na 'n kwarteeu. Historia se redaksie het 'n soortgelyke patroon gevolg. Die eerste nege redakteurs was almal by een bepaalde tersiêre instelling gesetel, en het eers met die daaropvolgende vyf na ander instellings gemigreer. Uit die sewentien redakteurs (waaronder ook 'n tweemanskap en 'n driemanskap), was nog net drie die afgelope dekade vroulik. Die huidige voorsitter is ook die genootskap se eerste vroulike hoof. Dit mag op die oog af as kritiek teen die HGSA voorkom, maar dit is ook 'n weerspieëling van die akademiese gemeenskap - nie net in Suid-Afrika nie, maar ook wat betref die kontinent en die wyer, internasionale gemeenskap. Dit is egter ook opmerklik dat, 'n halfeeu later, dit 'n jong, vroulike redakteur is wat opnuut die belangrikheid van die vakgebied vooropstel, en 'n beroep doen om deurgaans "te besin en te vernuwe" (sien redaksionele artikel).

In die 1986 uitgawe het die redaksie weereens sy sorg uitgespreek oor die kwynende belangstelling in geskiedenis. Drie dekades ná die HGSA se stigting was daar nie net ongemak oor die opvoedkundige stelsel nie, maar ook oor politici en die breër publiek wat, so is daar aangevoer, "moontlik wou ontsnap van 'n skuldgevoel oor die foute van die verlede". ${ }^{23}$ Die land was in die wurggreep van die krisisse wat die politieke oorgang voorafgegaan het, en daar was 'n beroep op die ontwikkeling van 'n historiese bewussyn onder die jeug, met die stelling dat "ons in 'n ander era leef, ' $n$ veranderde samelewing met gedeelde belange en probleme wat ons saam sal moet oplos". 24 Met die \#RhodesMustFall veldtog drie dekades daarna was daar diegene in die historiese gemeenskap wat bekommerd was dat 'n \#HistoryMustFall veldtog sou volg. Dit wou voorkom asof partydige uitsprake, verdraaide stellings en onkunde aan die orde van die dag was. Tog, vanuit hierdie maalstroom het daar ' $n$ nuwe blik op die verlede na vore getree, en 'n nuwe lewenskragtigheid wat, danksy die studentebewegings, tersiêre instellings en veral geskiedenisdepartemente dwarsoor die land gedwing het om betrokke te raak by vraagstukke oor transformasie, 'n herbesinning oor leerplanne en dekolonisasie. Dit is in vele opsigte 'n welkome verwikkeling, wat weereens die plek en die belangrikheid van Geskiedenis aan die voorpunt plaas.

22. Historia, 4 (Desember 1965), p 224.

23. Historia, 31 (Mei 1986), $\mathrm{p} 1$.

24. Historia, 31 (Mei 1986), p 1. 